\title{
PENGARUH SUHU AIR TERHADAP DAYA TETAS TELUR DAN PERKEMBANGAN LARVA NILA MERAH (Oreochromis sp.)
}

\section{EFFECT OF WATER TEMPERATURE ON EGG HATCHIBILITY AND LARVAE DEVELOPMENT OF RED NILA (Oreochromis sp.)}

\begin{abstract}
Rustadi*)
Abstract

Artificial incubations of red tilapia eggs and fry were conducted in the effort to increase fish seed production and its quality. These experiments were done to determine suitable water temperature for egg incubation and larvae rearing. Four different water temperatures, 24, 27, 30 , and $33^{\circ} \mathrm{C}$ with variance $1^{\circ} \mathrm{C}$ and ambient temperature were tested in triplicates. One liter of plastic incubators made from soft drink bottles were set to water re-circulation system and provided with filter means. The fertilized eggs were stocked at 150 eggs. The hatching rate of egg increased as the increase of water temperature. The increase of water temperature decreased the incubation time of eggs, but increased hatching rate and the growth of larvae. The optimum water temperature was $29,87^{\circ} \mathrm{C}$.
\end{abstract}

Key words : Egg hatchibility, larvae development, Oreochromis sp., water temperature

\section{Pengantar}

Inkubator yang dikenal sebagai Zoug jar adalah alat penetas telur ikan yang telah lama digunakan untuk hampir semua jenis ikan (Woynarovich dan Horvath, 1980). Inkubator ini dibuat dari gelas yang kemudian mengalami perubahan terutama mengenai bahannya, sedangkan prinsip operasionalnya tetap. Air dialirkan dari dasar alat yang berbentuk corong dan bergerak ke bagian atas inkubator. Aliran menghasilkan upwelling air sehingga menyebabkan telur selalu bergerak, berguling dan terjadi oksigenasi.

Teknik penetasan menggunakan inkubator dapat menghasilkan benih dengan umur yang sama. Keuntungan yang lain adalah masa inkubasi dan pengasuhan larva oleh induk betina tidak ada, maka waktunya digunakan untuk pematangan telur berikutnya sehingga frekuensi pemijahannya lebih banyak. Di samping itu, karena telur ditetaskan dalam lingkungan lebih terkontrol, maka memungkinkan memanipulasi faktor-faktor lingkungan yang berpengaruh pada penetasan telur maupun memanipulasi fase telur untuk mendapatkan benih yang berkualitas unggul.
Penggunaan inkubator untuk tilapia atau Oreochromis disarankan pertama oleh Rothbard dan Hulata (1980) dalam sistem resirkulasi tertutup. Kemudian Rana (1985) menggunakan inkubator (volume 1-3 liter) dalam penelitiannya mengenai perkembangan telur dan larva tilapia. Faktor yang mempengaruhi perkembangan telur selama inkubasi selain oksigen adalah suhu air (Woynarovich dan Horvath, 1980). Suhu air yang rendah menyebabkan proses metabolisme telur lambat, sehingga masa penetasan menjadi lama. Di samping itu, suhu air yang rendah merupakan lingkungan yang cocok untuk pertumbuhan jamur. Sebaliknya, apabila suhu air tinggi maka proses metabolisme akan cepat bahkan bisa menyebabkan abnormalitas, dan mematikan telur maupun larva. Oleh karena itu, penelitian pengaruh suhu air terhadap penetasan telur nila merah perlu dilakukan.

Tujuan penelitian ini untuk mengetahui pengaruh suhu air terhadap daya tetas telur, masa inkubasi dan perkembangan larva nila merah menggunakan inkubator. Inkubator dibuat dari botol plastik bekas soft drink hasil modifikasi seperti yang

*Staf Pengajar Jurusan Perikanan Fakultas Pertanian UGM, Jalan Sosio Justisia, Bulaksumur, Yogyakarta 
dirancang oleh Rottmann dan Shireman (1988). Model tersebut belum pernah dicoba untuk penetasan telur nila merah.

\section{Bahan dan Metode}

Penelitian dilakukan dengan percobaan penetasan telur nila merah (Oreochromis sp.) menggunakan inkubator. Perlakuan percobaan adalah suhu air inkubasi yang berbeda, yaitu: $\mathrm{P}_{1}$ (suhu air $24^{\circ} \mathrm{C}$ ), $\mathrm{P}_{2}$ (suhu air $27^{\circ} \mathrm{C}$ ), $\mathrm{P}_{3}$ (suhu air $30^{\circ} \mathrm{C}$ ), $\mathrm{P}_{4}$ (suhu air $33^{\circ} \mathrm{C}$ ) dan $\mathrm{P}_{0}$ (kontrol), yaitu suhu air inkubasi tidak diatur atau mengikuti suhu udara yang ada. Masingmasing perlakuan diulang tiga kali. Suhu perlakuan dijaga dalam fluktuasi $\pm 1{ }^{\circ} \mathrm{C}$. Penyusunan perlakuan berdasarkan purposive random, yaitu random dilakukan dalam satu perlakuan yang suhunya sama. Penetasan dilakukan dalam sistem aliran air balik (resirkulasi). Untuk membentuk suhu air di bawah suhu air yang ada digunakan alat pendingin (refrigerator), sedangkan di atas suhu air yang ada dengan alat pemanas (heater). Alat pendingin dan pemanas dipasang dalam akuarium.

\section{Alat penetasan}

Inkubator dibuat dari botol plastik bulat volume 1,25 liter. Panjang botol $30 \mathrm{~cm}$, terbagi atas bagian leher $3 \mathrm{~cm}$, bagian corong $9 \mathrm{~cm}$ dan tubuh $18 \mathrm{~cm}$. Diameter bagian leher $2,2 \mathrm{~cm}$ dan bagian tubuh 7,5 $\mathrm{cm}$. Lubang bagian leher dipasang pipa air masuk dari aluminium diameter $0,5 \mathrm{~cm}$ dan sisanya ditutup dengan campuran pasir halus dengan semen. Botol dipasang pada rak secara terbalik, sehingga bagian leher terletak di bawah. Pada bagian atas botol dipasang selang plastik (diameter 0,75 $\mathrm{cm}$ ) untuk pembuangan air sehingga membentuk volume inkubator 1 liter. Dari pipa aluminium dihubungkan dengan selang plastik ke akuarium penampungan air ukuran $60 \times 40 \times 40 \mathrm{~cm}$.

Di dalam akuarium dipasang alat pemanas (Automatic Water Heater model Rena F 150 Watt) atau pendingin otomatis yang dapat mengatur suhu air yang diinginkan.
Air dari akuarium dipompa ke atas melalui pipa plastik berdiameter $2 \mathrm{~cm}$ terbagi dua yang dapat diatur debitnya, yaitu ke arah botol-botol inkubator dan satunya kembali ke akuarium. Pipa plastik yang ke arah inkubator dibagi tiga, masing-masing masuk ke dalam botol melalui pipa aluminium tepat $0,5 \mathrm{~cm}$ dari dasar bawah botol. Botol inkubator sebanyak tiga buah dipasang pada satu unit. Sepertiga bagian akuarium digunakan untuk tempat penyaringan air yang berasal dari inkubator. Penyaringan berisi bahan-bahan yang disusun dari atas ke bawah meliputi: pasir, ijuk dan kerakal.

\section{Telur}

Telur diperoleh dari hasil pemijahan menggunakan jaring hapa ukuran lubang 2 $\mathrm{mm}$. Jumlah jaring yang digunakan delapan buah yang ditempatkan di dalam dua kolam. Ukuran tiap jaring hapa $2 \times 1 \times 1 \mathrm{~m}$, kedalaman air $60 \mathrm{~cm}$ ditebari enam ekor induk betina dan dua ekor induk jantan. Ukuran induk betina 200-250 gram, sedangkan induk jantan 250-300 gram. Pakan ikan terapung berbentuk pelet dengan kandungan protein antara $32-34 \%$ diberikan untuk induk sebanyak dua persen biomasa tiap hari.

Tiga hari setelah pelepasan induk, telur yang telah dibuahi diambil dari induk yang mengeraminya. Pengambilan telur dilakukan dengan membuka mulut induk betina dalam wadah yang berisi air, induk dibiarkan bernafas kemudian telur disemburkan bersama air keluar.

Percobaan dilaksanakan di Laboratorium Akuakultur Jurusan Perikanan, Fakultas Pertanian UGM.

\section{Prosedur percobaan}

Sebelum digunakan, inkubator, wadah dan alat-alat untuk mengambil telur dicuci dengan alkohol $10 \%$, sedangkan air yang digunakan diberi larutan Malachite green dengan konsentrasi 0,2 ppm. Seluruh akuarium diisi air sebanyak 18 liter, kemudian pompa dihidupkan dan debit air 
diatur berkisar antara 0,2-0,3 liter per menit.

Telur yang berasal dari lima induk dipilih yang seragam berwarna kuning cream dan jumlahnya mencukupi. Telur yang dipilih adalah dari tiga induk, kemudian dihitung dengan metode individual (Effendi, 1978; Weatherley, 1972) dan dibagi menjadi lima kelompok. Tiap kelompok sebanyak 150 butir yang selanjutnya dimasukkan ke dalam inkubator. Setelah telur ditebarkan suhu mulai diatur sesuai dengan perlakuan, penyesuaian suhu air ini berjalan sekitar 30 menit.

Kualitas air dalam akuarium dan air keluar dari inkubator diamati setelah telur ditebar, menetas dan menjelang akhir percobaan. Parameter kualitas air meliputi: suhu, kekeruhan, konduktivitas, $\mathrm{pH}$ air, $\mathrm{O}_{2}$ terlarut (DO), $\mathrm{CO}_{2}$ dan alkalinitas. Pengamatan kualitas air menggunakan TOA Water Quality Checker tipe WQC20A. Suhu air diamati setiap hari untuk mengetahui kisarannya.

Tiap hari telur diambil sebanyak $10 \%$ dari jumlah total per inkubator untuk mengecek perkembangan penetasan. Jumlah telur yang menetas dan mati dihitung per inkubator. Jumlah dan ukuran benih larva setelah kantong telurnya habis juga dihitung.

Daya tetas telur (\%) adalah perbandingan antara jumlah telur yang menetas dengan jumlah telur yang ditebarkan (150 butir) tiap inkubator dikalikan $100 \%$. Masa inkubasi merupakan penjumlahan masa penetasan telur dan masa kantong telur larva habis: a). Masa penetasan telur: waktu (jam atau hari) yang diperlukan untuk perkembangan telur sejak dimasukkan ke dalam inkubator sampai menetas, b). Masa kantong telur larva habis: waktu (jam atau hari) yang diperlukan untuk perawatan larva dari sejak menetas sampai kantong telurnya habis. Ukuran telur dan larva juga diamati. Daya tetas telur dianalisis menggunakan analisis varian dan korelasi dengan tingkat kepercayaan 95\% (Gomez dan Gomez,
1976). Masa inkubasi, ukuran telur dan larva serta kualitas air dianalisis secara deskriptif.

\section{Hasil dan Pembahasan}

\section{Daya tetas telur}

Hasil inkubasi telur nila merah yang menetas, telur tidak menetas dan yang hancur disajikan dalam Tabel 1. Telur yang tidak menetas berupa telur yang masih utuh berwarna putih pucat dan tidak berwujud, yaitu hancur terlarut dalam air.

Daya tetas telur terbanyak adalah pada perlakuan P4 dan P3 masing-masing sebanyak 59,33\%, diikuti P2 sebanyak $49,33 \%$ dan terendah P1 sebanyak $48,22 \%$, sementara kontrol sebanyak $52,0 \%$.

Meskipun tidak berbeda nyata diantara perlakuan, rata-rata daya tetas telur cenderung naik dengan semakin tinggi suhu. Tidak adanya pengaruh suhu terhadap daya tetas telur tersebut karena kisaran suhu perlakuan $\left(24-33^{\circ} \mathrm{C}\right)$ masih dalam kisaran yang sesuai bagi perkembangan embrio dan penetasan telur nila merah. Batas toleransi perkembangan embrio nila hitam (Oreochromis niloticus) yang merupakan spesies penurun nila merah adalah $17-20{ }^{\circ} \mathrm{C}$ untuk suhu rendah, sedangkan untuk suhu tingginya adalah $34,5-39,5^{\circ} \mathrm{C}$ (Rana, 1988).

Suhu ambien (kontrol) yang berkisar 26,8 $28,95{ }^{\circ} \mathrm{C}$ terlihat menghubungkan suhu perlakuan P2 dengan P3, yang menghasilkan daya tetas $52,0 \%$ sehingga meyakinkan kecenderungan daya tetas telur yang semakin naik dengan semakin tinggi suhu. Namun hanya sampai pada suhu $33^{\circ} \mathrm{C}$ (P4) menghasilkan daya tetas yang sama dengan pada suhu $30^{\circ} \mathrm{C}$ (P3). Maka diperkirakan pada suhu yang lebih tinggi daripada $33^{\circ} \mathrm{C}$ akan menurunkan daya tetas telur. Sebaliknya pada suhu air yang lebih rendah, perkembangan embrio dan penetasan telur bisa terhambat.

Hubungan antara daya tetas telur dan suhu air adalah kuadratik dengan 
persamaan $y=-282,01+22,67 x-0,38 x^{2}(r=$ $0,13)$. Oleh karena itu dapat diperoleh suhu optimum untuk penetasan telur nila merah, yaitu $29,87{ }^{\circ} \mathrm{C}$. Grafik hubungan antara suhu air inkubasi dengan daya tetas telur dapat dilihat pada Gambar 1.

Menurut Thomopoulus (1954) dalam Smith (1957) suhu rendah dapat menghambat proses aktivasi, diferensiasi dan perkembangan perivetilin dalam pembentukan zigot dan pelunakan chorion telur. Disamping itu, sekresi dan aktivitas enzim proteolitik yang berfungsi dalam pemecahan chorion juga terhambat karena suhu yang lebih rendah (Hayes, 1942 dalam Smith, 1957; Woynarovich dan Horvath, 1980). Dengan demikian suhu air inkubasi yang paling cocok untuk penetasan telur nila merah adalah berkisar $27-33^{\circ} \mathrm{C}$, dengan dosis optimum $29,87^{\circ} \mathrm{C}$.

Tabel 1. Rata-rata jumlah telur yang menetas dan tidak menetas tiap perlakuan

\begin{tabular}{ccccc}
\hline Perlakuan & Kisaran suhu & Telur menetas & \multicolumn{2}{c}{ Telur tidak menetas } \\
\cline { 4 - 5 } Suhu air $\left({ }^{\circ} \mathrm{C}\right)$ & aktual $\left({ }^{\circ} \mathrm{C}\right)$ & $(\%)$ & Utuh $(\%)$ & Hancur $(\%)$ \\
\hline $\mathrm{P} 1=24$ & $23,0-25,0$ & $48,22^{\text {a }}$ & 46,45 & 5,33 \\
$\mathrm{P} 2=27$ & $25,5-27,0$ & $49,33^{\mathrm{a}}$ & 35,33 & 15,34 \\
$\mathrm{P} 3=30$ & $29,2-31,0$ & $59,33^{\mathrm{a}}$ & 21,34 & 19,33 \\
$\mathrm{P} 4=33$ & $32,0-33,0$ & $59,33 \mathrm{a}$ & 25,34 & 15,33 \\
$\mathrm{P} 0=$ Kontrol & $26,8-28,5$ & $52,00^{\mathrm{a}}$ & 37,33 & 10,67 \\
\hline
\end{tabular}

Keterangan : Rata-rata dalam kolom yang diikuti huruf sama menunjukkan tidak ada beda nyata

Tabel 2. Masa telur menetas dan kuning telur larva habis pada setiap perlakuan

\begin{tabular}{cccc}
\hline Perlakuan & $\begin{array}{c}\text { Masa telur menetas } \\
\text { (jam=hari) }\end{array}$ & $\begin{array}{c}\text { Masa kuning telur } \\
\text { habis (jam=hari) }\end{array}$ & $\begin{array}{c}\text { Masa inkubasi } \\
\text { (jam=hari) }\end{array}$ \\
\hline P1 & $138=5,75$ & $144,0=6,00$ & $282,0=11,75$ \\
P2 & $114=4,75$ & $119,0=4,96$ & $233,0=9,71$ \\
P3 & $72=3,00$ & $5295,5=3,98$ & $167,5=6,98$ \\
P4 & $51=2,12$ & $63,5=2,65$ & $114,5=4,77$ \\
P0 & $90=3,75$ & $104,0=4,33$ & $194,0=8,08$ \\
\hline
\end{tabular}

Tabel 3. Ukuran telur dan hasil penetasan pada setiap perlakuan

\begin{tabular}{|c|c|c|c|c|c|c|c|}
\hline \multirow[b]{2}{*}{ Perlakuan } & \multicolumn{3}{|c|}{ Telur } & \multicolumn{2}{|c|}{ Larva baru } & \multicolumn{2}{|c|}{ Benih umur 8 hari } \\
\hline & $\begin{array}{c}\text { Jumlah } \\
\text { (butir) }\end{array}$ & Dimensi & $\begin{array}{l}\text { Diameter } \\
(\mathrm{mm})\end{array}$ & $\begin{array}{c}\text { Jumlah } \\
\text { (ekor) }\end{array}$ & $\begin{array}{c}\text { Panjang } \\
\text { (cm) }\end{array}$ & $\begin{array}{c}\text { Jumlah } \\
\text { (ekor) }\end{array}$ & $\begin{array}{l}\text { Panjang } \\
\text { (cm) }\end{array}$ \\
\hline P1 & 45 & $\begin{array}{l}\text { Pendek } \\
\text { Paniana }\end{array}$ & $\begin{array}{l}1,9-2,2 \\
20-24\end{array}$ & 19 & $0,4-0,5$ & 15 & 9,35 \\
\hline P2 & 45 & $\begin{array}{l}\text { Pendek } \\
\text { Panjang }\end{array}$ & $\begin{array}{l}1,8-2,2 \\
2,0-2,4\end{array}$ & 17 & $0,4-0,6$ & 15 & 10,05 \\
\hline P3 & 45 & $\begin{array}{l}\text { Pendek } \\
\text { Panjang }\end{array}$ & $\begin{array}{c}1,9-2,2 \\
2,0-2,4\end{array}$ & 26 & $0,5-0,6$ & 13 & 10,96 \\
\hline P4 & 45 & $\begin{array}{l}\text { Pendek } \\
\text { Panjang }\end{array}$ & $\begin{array}{r}1,9-2,2 \\
2,0-2,4\end{array}$ & 27 & $0,5-0,6$ & 15 & 11,60 \\
\hline P0 & 45 & $\begin{array}{l}\text { Pendek } \\
\text { Panjang }\end{array}$ & $\begin{array}{l}1,9-2,2 \\
2,0-2,4\end{array}$ & 23 & $0,4-0,6$ & 15 & 10,26 \\
\hline
\end{tabular}




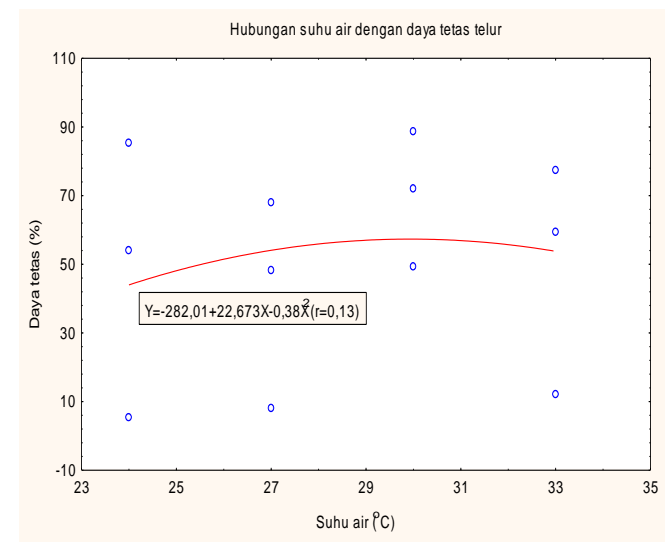

Gambar 1. Hubungan suhu air dengan daya tetas telur

Telur yang tidak menetas terbagi menjadi telur yang masih utuh berwarna putih pucat dan hancur terlarut dalam air. Telur nila merah yang tidak menetas lebih disebabkan karena tingkat kesuburan yang berbeda daripada pengaruh perlakuan. Hasil penelitian Rustadi (1996) menunjukkan bahwa tingkat kematangan telur nila merah berbeda-beda, baik dalam satu individu induk maupun induk yang berbeda. Tingkat kematangan telur yang berbeda tersebut diperkuat dengan adanya telur sisa (residual eggs) yang ditemukan dalam satu ovari (Peters, 1983).

Hasil penetasan telur yang berkisar 48,22$59,33 \%$ ini merupakan keberhasilan percobaan sebelumnya yang tidak sampai menetas. Namun hasil ini masih bisa ditingkatkan karena dari percobaan penetasan telur nila hitam bisa menghasilkan daya tetas $60 \%$ (Shaw dan Aronson, 1954 dalam Rana, 1988).

\section{Masa penetasan dan masa inkubasi}

Baik masa penetasan telur maupun masa kuning telur larva habis terpendek pada suhu air inkubasi tertinggi (P4) masingmasing selama 51 jam (2,12 hari) dan 63,5 jam (2,64 hari), sedangkan masa terlama pada perlakuan suhu air terendah (P1) masing-masing 138 jam (5,75 hari) dan 144 jam (6 hari). Oleh karena suhu kontrol termasuk dalam kisaran suhu perlakuan, maka masa penetasan telurnya berada di antara suhu $27^{\circ} \mathrm{C}$ (P2) dan suhu $30{ }^{\circ} \mathrm{C}$ (P3), yaitu selama 90 jam (3,75 hari) dan habisnya kantong selama 104 jam (4,33 hari). Dengan demikian masa inkubasinya adalah berkisar 114,5 jam (4,47 hari) sampai 282,0 jam (11,75 hari).

Dengan demikian masa telur menetas, habisnya kuning telur dan masa inkubasi semakin pendek waktunya dengan semakin tinggi suhu air. Masa penetasan telur maupun masa habisnya kantong telur larva dipengaruhi oleh suhu air inkubasi. Needham (1942) dalam Smith (1957) menyatakan bahwa semakin tinggi suhu air inkubasi semakin cepat perkembangan embrio. Dalam suhu air inkubasi yang lebih tinggi juga lebih meningkatkan sekresi dan aktivitas ensim proteolitik. Lebih lanjut dikemukakan oleh Rana (1988) bahwa waktu penetasan telur nila hitam ( $O$. niloticus) berhubungan linier dengan suhu air, yaitu pada suhu $17^{\circ} \mathrm{C}$ selama 8 hari sedangkan pada suhu $34,5^{\circ} \mathrm{C}$ selama 2,3 hari.

Menurut Needham (1942) dalam Smith (1957), perkembangan embrio semakin cepat dengan makin tinggi suhu. Meskipun demikian pada awal perkembangan, suhu air tidak boleh terlalu rendah atau terlalu tinggi, karena menurut Rana (1988) toleransi telur nila hitam (O. niloticus) semakin rendah dengan semakin cepat fase perkembangannya. Pada suhu 39,5 ${ }^{\circ} \mathrm{C}$ telur rusak, sedangkan pada suhu 17 ${ }^{\circ} \mathrm{C}$ terjadi penghambatan perpindahan sitoplasma pada kutub inti dan akhirnya terjadi kematian. Dengan demikian, batas toleransi suhu yang ekstrim untuk perkembangan zigot nila hitam adalah berkisar $17-20{ }^{\circ} \mathrm{C}$ untuk suhu rendah dan berkisar 34,5-39,5 ${ }^{\circ} \mathrm{C}$ untuk suhu tinggi. Oleh karena suhu air yang rendah atau tinggi berpengaruh negatif terhadap penetasan telur, maka perlu mempertahankan suhu optimum untuk penetasan telur dan perawatan larvanya berkisar $27-33^{\circ} \mathrm{C}$. 


\section{Ukuran telur, larva dan benih}

Ukuran telur, larva dan benih umur 8 hari dapat dilihat pada Tabel 3. Pada awalnya tiap individu telur dalam setiap kelompok berukuran relatif seragam dan berbentuk elips dengan ukuran diameter pendek berkisar 1,8-2,2 dan diameter panjang 2,0-2,4 mm. Dalam perkembangan selanjutnya telur yang fertil secara visual tampak berwarna kuning kehijauan, sedang yang tidak dibuahi berwarna kuning keputihan atau kuning pucat. Berdasarkan hasil pengamatan secara mikroskopis, perkembangan embrio masih dalam fase blastula dengan umur 10-14 jam sesudah pemijahan. Sebagai perbandingan, telur nila hitam yang telah dibuahi berbentuk elips berukuran $1,65 \times 2,00 \mathrm{~mm}$ sampai $2,60 \times 3,15 \mathrm{~mm}$ dan berwarna kuning tanah (Peters, 1983; Rana, 1988).

Ukuran larva hasil telur berkisar 0,4-0,6 $\mathrm{cm}$, sedangkan benih umur 8 hari berkisar 9,35-11,60 cm. Dari Tabel 3 dapat diketahui bahwa ada korelasi ukuran panjang larva dengan suhu air inkubasi. Pada perlakuan suhu rendah (P1) ukuran panjang larva kecil berkisar $0,4-0,5 \mathrm{~cm}$, pada perlakuan P2 dan kontrol ukuran bervariasi $0,4-0,6 \mathrm{~cm}$, pada perlakuan $\mathrm{P} 3$ dan P4 (suhu tinggi) ukurannya lebih besar berkisar 0,5-0,6 cm. Kecenderungan lebih jelas ditemukan pada ukuran benih umur 8 hari, panjang benih semakin besar dengan semakin tinggi suhu air inkubasi, yaitu berkisar $9,35 \mathrm{~cm}$ sampai $11,60 \mathrm{~cm}$.

\section{Kualitas air}

Data kualitas air yang merupakan hasil pengamatan ketika telur baru ditebar, setelah menetas dan pada akhir masa inkubasi, disajikan dalam Tabel 4.

$\mathrm{O}_{2}$ terlarut, $\mathrm{CO}_{2}$ bebas, $\mathrm{pH}$, alkalinitas dan turbiditas air terlihat tidak terpengaruh oleh perlakuan suhu. Nilainya masing-masing hampir sama di antara perlakuan. Kandungan $\mathrm{O}_{2}$ dalam air berkisar 3,7-7,3 $\mathrm{mg} / \mathrm{l}$, sedangkan kandungan $\mathrm{CO}_{2}$ bebas berkisar 2,0-5,0 mg/l. Kualitas air lainnya adalah $\mathrm{pH}$ berkisar 8,35-8,97, alkalinitas berkisar $56-64 \mathrm{mg} / \mathrm{l}$ dan turbiditas berkisar $222-227 \mathrm{mg} / \mathrm{l}$.

Faktor-faktor utama yang mempengaruhi penetasan telur dan perkembangan larva adalah: suhu air, penyinaran dan $\mathrm{O}_{2}$, kandungan $\mathrm{CO}_{2}$ serta salinitas (Smith, 1957; Piper dkk., 1982). Namun selain suhu air, belum ada studi tentang nilai kualitas air yang baku untuk penetasan telur dan perawatan larva.

Menurut Lindroth (1966) dalam Huisman (1976) kebutuhan $\mathrm{O}_{2}$ pada awal penetasan bisa diabaikan, tetapi setelah mengalami perkembangan bisa naik 10 kali. Kandungan $\mathrm{O}_{2}$ terlarut yang rendah (kurang dari $0,5 \mathrm{mg} / \mathrm{l}$ ) menghambat perkembangan dan pelepasan telur, menurunkan fekunditas dan daya tetas telur (Wedemeyer dkk., 1990). Kandungan $\mathrm{CO}_{2}$ bebas yang baik untukpemijahan adalah kurang dari $60 \mathrm{mg} / \mathrm{l}$ (Ellis, 1937 dalam Boyd, 1979), sedang $\mathrm{pH}$ berkisar 6,5-9 dan alkalinitas berkisar 20-150 ppm (Boyd, 1979).

Tabel 4. Kisaran nilai kualitas air selama percobaan

\begin{tabular}{cccccc}
\hline Perlakuan & $\begin{array}{c}\mathrm{O}_{2} \\
(\mathrm{mg} / \mathrm{l})\end{array}$ & $\begin{array}{c}\mathrm{CO}_{2} \\
(\mathrm{mg} / \mathrm{l})\end{array}$ & $\mathrm{pH}$ & $\begin{array}{c}\text { Alkanitas } \\
(\mathrm{mg} / \mathrm{l})\end{array}$ & $\begin{array}{c}\text { Turbiditas } \\
(\mathrm{mg} / \mathrm{l})\end{array}$ \\
\hline P1 & $5,2-6,6$ & $2,0-2,4$ & $8,89-8,94$ & $57-63$ & $224-227$ \\
P2 & $4,8-6,4$ & $2,0-3,0$ & $8,49-8,97$ & $58-64$ & $223-226$ \\
P3 & $3,7-5,4$ & $2,0-3,0$ & $8,35-8,67$ & $56-64$ & $222-223$ \\
P4 & $4,0-5,3$ & $2,8-5,0$ & $8,55-8,68$ & $63-64$ & $220-222$ \\
P0 & $4,4-5,8$ & $2,0-4,0$ & $8,43-8,80$ & $58-63$ & $223-225$ \\
\hline
\end{tabular}


Dengan demikian parameter kualitas air yang diukur memenuhi syarat untuk penetasan telur. Namun parameter lain terutama gas $\mathrm{NH}_{3}$ yang tidak diamati dan bersifat racun bisa merupakan salah satu faktor yang menyebabkan rendahnya daya tetas telur. Meskipun demikian, inkubator yang dirancang dan digunakan telah dapat membuat telur bergerak bergulung (rolling), baik dengan aliran air maupun aerasi, sehingga menyerupai perlakuan dalam rongga mulut induk betina. Debit air yang masuk ke dalam inkubator volume sepuluh liter pada awal adalah $0,2 \mathrm{~L} /$ menit, kemudian setelah akhir fase blastophore meningkat berkisar 0,5 - $1 \mathrm{~L} /$ menit. Di samping itu, dalam inkubator corong, aliran air dapat memisahkan telur satu sama lain, menggerakkan secara bergulung, mencampur terus menerus, menyuplai $\mathrm{O}_{2}$ dan membuang bahan ekskresi (Woynarovich dan Horvath, 1980).

\section{Kesimpulan dan Saran}

\section{Kesimpulan}

a. Pengaruh suhu air dalam inkubator berkisar $27-33^{\circ} \mathrm{C}$ terhadap daya tetas telur nila merah (Oreochromis sp.) membentuk persamaan kuadratik $\mathrm{y}=$ $282,01+22,67 x-0,38 x^{2} \quad(r=0,13)$ dan dengan suhu optimum $29,87^{\circ} \mathrm{C}$.

b. Telur nila merah berbentuk elips, diameter pendek berkisar 1,8-2,2 mm dan panjang 2,0-2,4 $\mathrm{mm}$. Ukuran larva berkisar 0,4-0,6 $\mathrm{cm}$ sedangkan benih umur 8 hari berkisar $9,35-11,60 \mathrm{~cm}$.

c. Masa penetasan telur dan kantong telur larva habis (masa inkubasi) cenderung makin singkat dengan semakin tinggi suhu air. Dalam kisaran suhu 24-33 ${ }^{\circ} \mathrm{C}$ diperlukan waktu untuk penetasan telur 51-138 jam dan kantong telurnya habis 63,5-144 jam.

d. Kualitas air selama masa inkubasi masih cukup baik untuk penetasan telur dan larva.

\section{Saran}

a. Perlu upaya peningkatan kesuburan telur per individu melalui perbaikan induk, pakan dan rasio induk dalam pemijahan.

b. Perlu penelitian manipulasi suhu air untuk mempercepat pertumbuhan larva.

\section{Ucapan Terima Kasih}

Penghargaan dan terima kasih disampaikan kepada Universitas Gadjah Mada melalui Lembaga Penelitian, yang telah memberikan bantuan biaya untuk pelaksanaan penelitian ini. Terima kasih juga disampaikan kepada Saudarasaudari: Yati, Nita dan Wandi atas bantuannya dalam melaksanakan penelitian.

\section{Daftar Pustaka}

Boyd, C.E.. 1979. Water Quality in Warmwater Fish Ponds. Auburn University, Auburn Alabama. 359 p.

Effendie, M.I.. 1978. Biologi Perikanan. Bagian II. Fakultas Perikanan, IPB. Bogor. 105 hal.

Gomez, K.A. and A.A. Gomez. 1976. Statistical Procedures for Agricultural Research with Emphasis on Rice. International Rice Research Institute, Los Banos. 294 p.

Huisman, E.A.. 1976. Hatchery and Nursery Operations in Fish culture management, in Aspects of Fish Culture and Breeding ed. by E.A. Huisman. $H$. Veeman and Zonen B.V. Wageningen. 29-50p.

Peters, H.M.. 1983. Fecundity, Egg Weight and Oocyte Development in Tilapias (Cichlidae, Teleostei). Translated from Germany and 
edited by D. Pauly. ICLARM Manila, $28 \mathrm{p}$.

Piper, R.G., I.B. McElwain, L.E Orme, J.P. McCraren, L.G. Fowler, J.R. Leonard. 1982. Broodstock, Spawning and Egg Handling, in Fish Hatchery Management. US Dept. of the Interior, Fish and Wildlife Service Washington D.C. 348-368 p.

Rana, K., 1985. Influence of Egg Size on the Growth, Onset Feeding, Point-of-No-Return, and Survival of Unfed Oreochromis mossambicus Fry. Aquaculture. 46: 119-131.

Rana, K., 1988. Reproductive Biology and the Hatchery Rearing of Tilapia Eggs and Fry. In Recent Advances in Aquaculture ed. by J.F. Muir and R.J. Roberts. Aquaculture, 3: 343-406

Rothbard, S. and G. Hulata, 1980. Closed Incubator for Cichlid Eggs. Progr. Fish-Cult. 42: 203-204.

Rottmann dan Shireman, 1988. Hatching Jar That is Inexpensive and
Simple to Assemble. Progr. FishCult. 40: 57-58.

Rustadi. 1996. Pengambilan Telur dari Induk Nila Merah (Oreochromis sp.), Pengaruhnya Terhadap Daya Tetas dan Kecepatan Induk Betina Berpijah Kembali. Lap. penel. lemb. pen. UGM. Yogyakarta. 31 hal.

Smith, S., 1957. Early Development and Hatching in Physiology of Fishes, M.E. Brown. (Eds.) vol. I Metabolism. Academic Press Inc., New York. 287-317 p.

Weatherley, A.H. 1972. Growth and Ecology of Fish Population. Academic Press, Inc. 293 hal.

Wedemeyer, G.A., A.B. Barton, D.J. Mc.Leay, 1990. Stress and Acclimatization , pp. 451-489. in Shreck, C.B. and P.B. Moyle (eds.) Methods for Fish Biology. American Fisheries Society. Bethesda, MD. USA.

Woynarovich, E. and L. Horvath, 1980. The Artificial Propagation of Warmwater Finfish. FAO Fish Tech. Pap. 201: 183 p. 